\title{
楛要約下ニ於ヶル村田氏反應成績ノ動搖 二就テ
}

\author{
厚生省保險院社會保險局 \\ 繁士 太田長”次 郎 \\ Chojiro Ota
}

（昭和16年 8 月 28 日受付）

\section{【内 容 抄 錄】}

村田氏徽毒血清反應ガ, 溫度/高低, 其 /急激ナ㷊換及ビ試樂調製=使用ス几活水/溫度操作

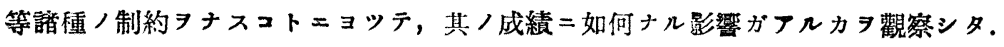

目

次

第 1 章 粕 言

第 2 章 研究方法兹 $=$ 筫驗材料

第 1 節 研究方法

第 2 節 實驗材料

第 3 算 實驗成績

第 1 節 水室室溫及脬卵器內 $=$ 放置七几場 合
第 2 節 活水 $\exists 30$ 度 $=$ 加溫シタ几場合

第 3 節 活水 $习$ 零度 $=$ 冷却シタ儿場合

第 4 節 睬卵器 $\Xi$ リ水室二置換 2 場合

第 5 節 水室 $\exists リ$ 娐㥸器 $=$ 置換七几埸合

第 4 章 總括蓝 $=$ 考察

第 5 章 結 緰

女。献

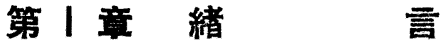

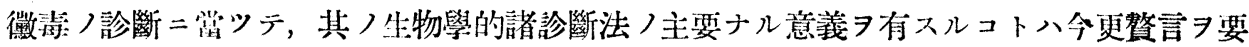

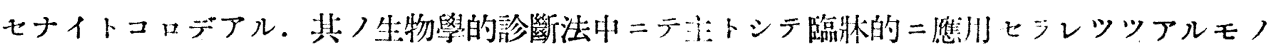

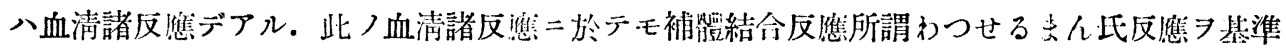

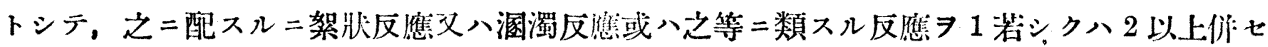
行フ要アルコトハ周知ノ事貫デアル。

狗里, 中村, 清水, 田中氏等つわつせるまん氏反應標準術式二關スル研究業績二於テモ此 ノ點ヨ强調シティル. 而シテ現下我國ノ狀况トシテハ此ノ補助的反應トシテ多ク村田氏法 探用シツツアリ, 少數ニハ小林, 田岡, 西村氏法 (北里研究所法) 或ハさつくす・げおるき 一氏法ガ行ハレテキル．最近ニハ井出氏法ガ普及シツッアル現狀デアル．

抑々村田氏法八北里研究所法ノ如ク反應時ノ溫度シー莡ニスルコトナク，浮動的ナ可變的 


太田 長 次 郎 进

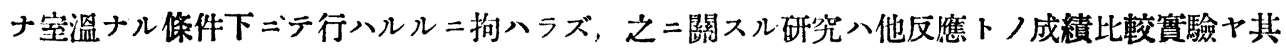

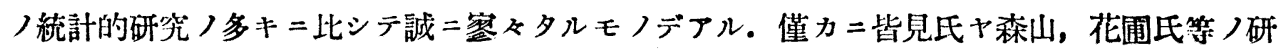
究報告ガアル二過ギナイ．從ツテ余八此點＝關スル追試ヨ行フノモ徒爾デハナイモノト思量 シ，本賽驗

\section{第 2 章 研究方法並二實驗材料}

\section{第 1 䇤 研 究 方 法}

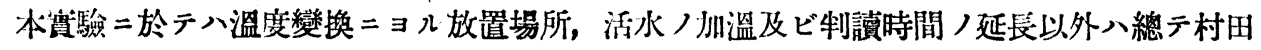
氏反隹ノ原法二從七, 可檢血清モ同一ノモノ （1）室溫=放置七儿群，（2）37度孵卵器內

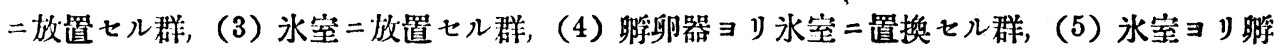

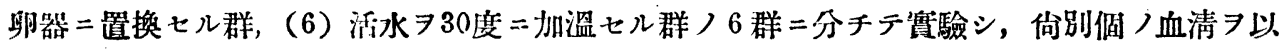

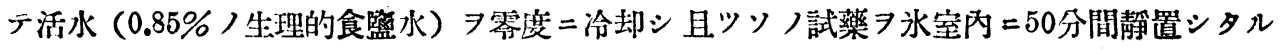
後可檢血清二重管シ，引續キ水空內二放置シタル場合モ貫驗シタノデアル。

\section{第 2 筫 實 驗 材 料}

惯驗材料トシテ川ヒタ村田氏反應用徽毒診斷液八暨野義商店發賣ノモノニシテ, 檢查器具

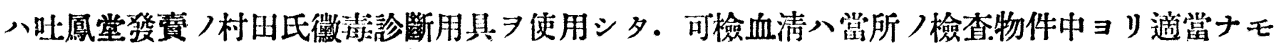
ノヨ撰定シテ實驗二供シタ。

\section{第 3 童 實 驗 成 績}

\section{第 | 第水室, 室温及粰卵器內二放置七ル場合}

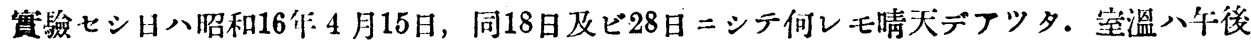
2 時渔定二テ攝氏19港8分 (15日) 同18度6分 (18日) 同18度2分 (28日) =シテ，村田氏徽毒 診斷依习稀釋スルタメ

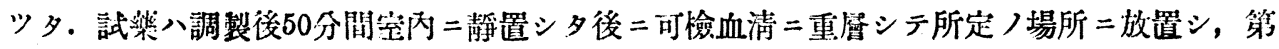

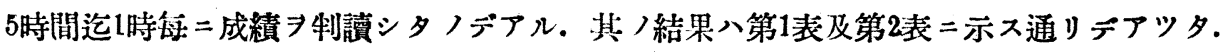

前 2 表ニヨツテ明カナル如ク, 水室內靜置ノ場合八室溫放置ノモノニ此シテ反應時間ガ遲 延シ，室溫故通 3 時間 $=$ 相當スル成績八第 4 時間乃至第 5 時間 =シテ澾成ヒラレルカ，之二反

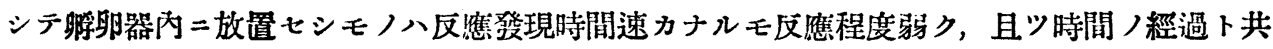
二次第二消退スル. 又睬卵器內靜置ノモノ八弱陽性程度以下ノ反應八震々發現シナイコトガ アルシ，第 3 時間二於テ白輪上面ガ雲絮狀ヨ呈シテ來テ成績ノ制讀二困難ヨ來スモノガ現八 レテクル。 


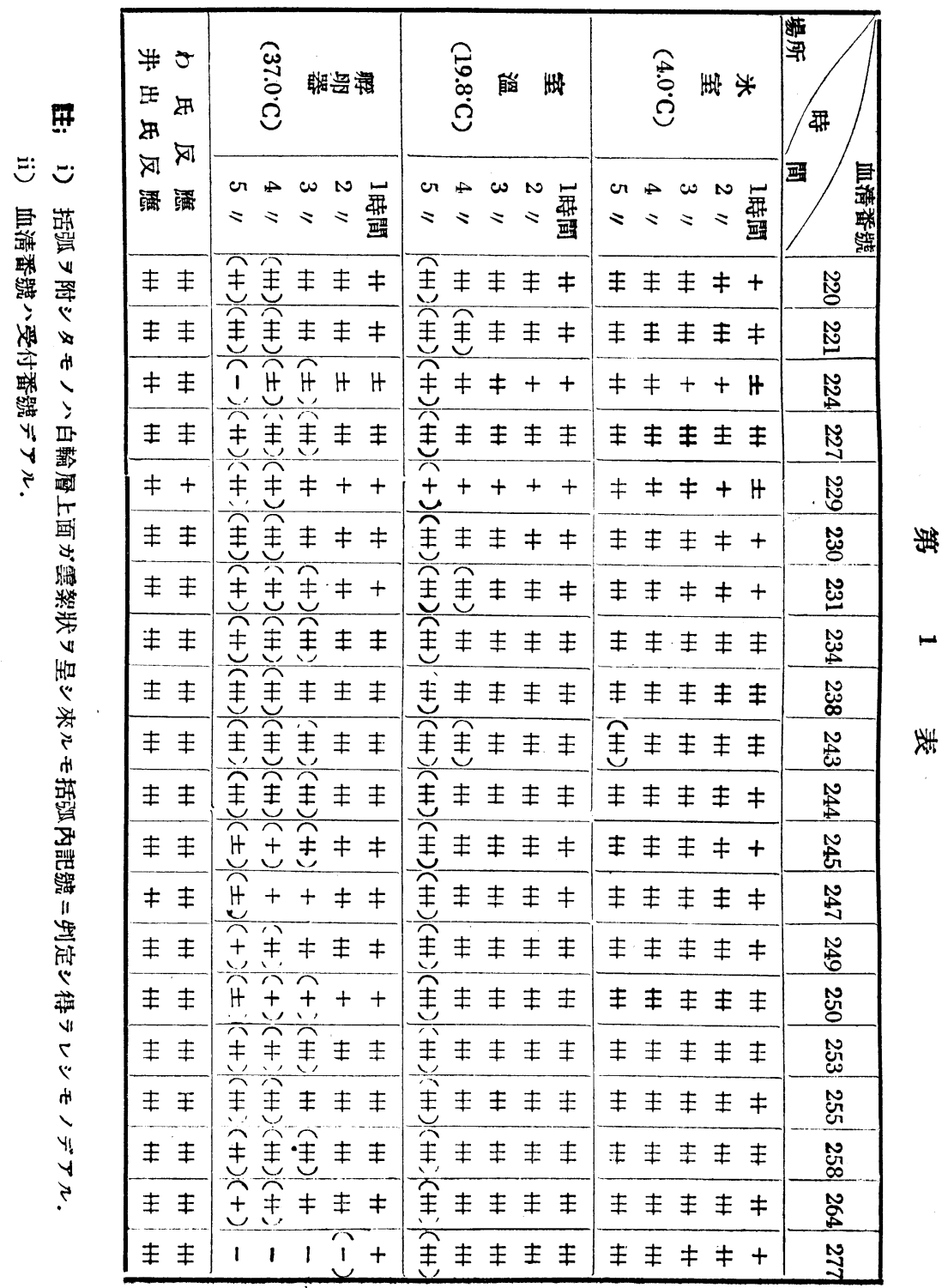


太田晨次郎 …迅

(597)

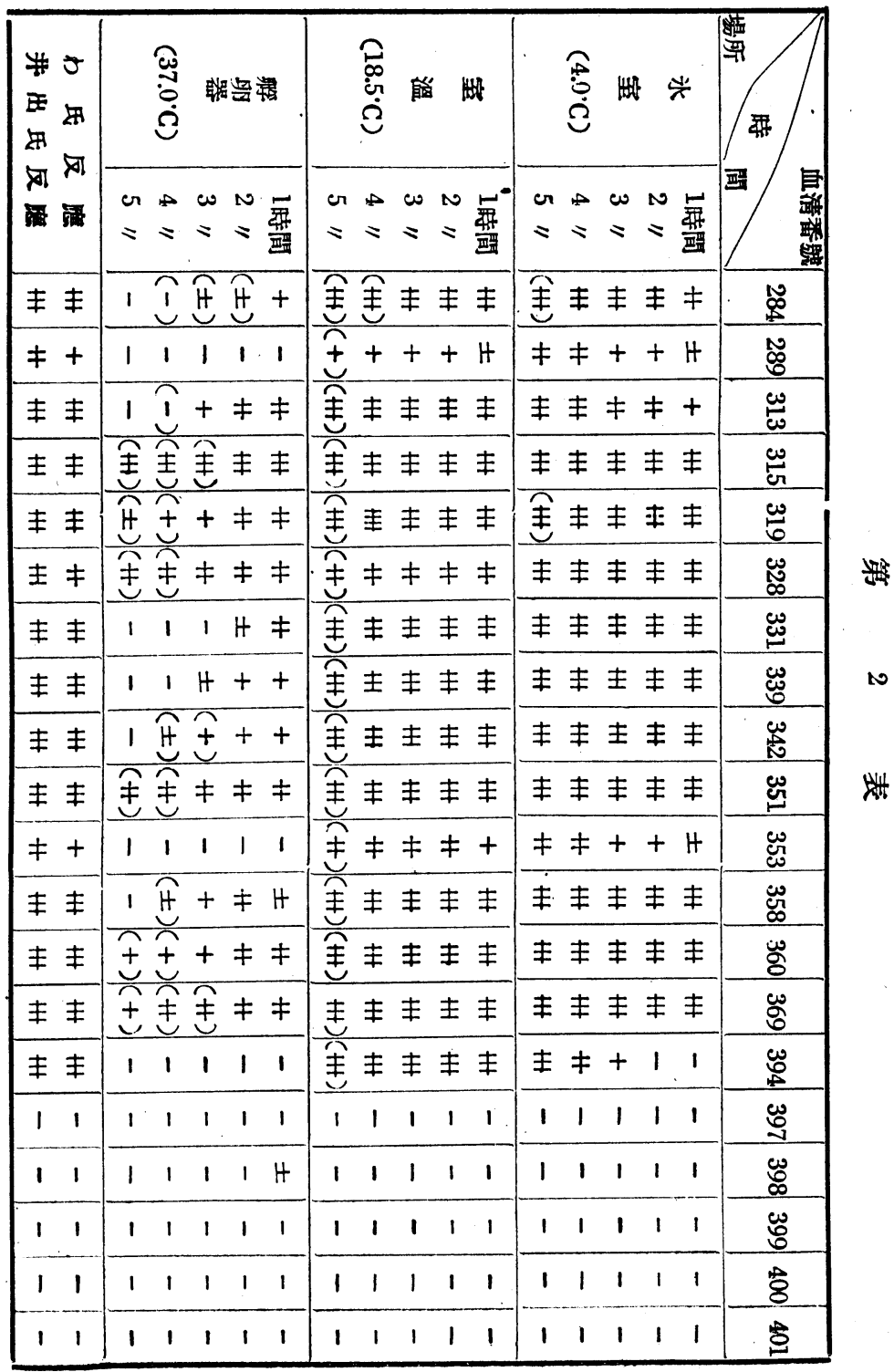

第 2 第 活水 $\Rightarrow 30^{\circ} \mathrm{C}=$ 加溫シタル場合

活水 7 攝氏 30 度 $=$ 加溫シテ, 直チ $=$ 試樂 7 調製シ, 之 750 分間室温 $=$ 放圆シテカラ可檢血

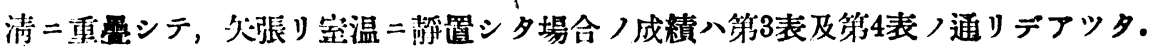



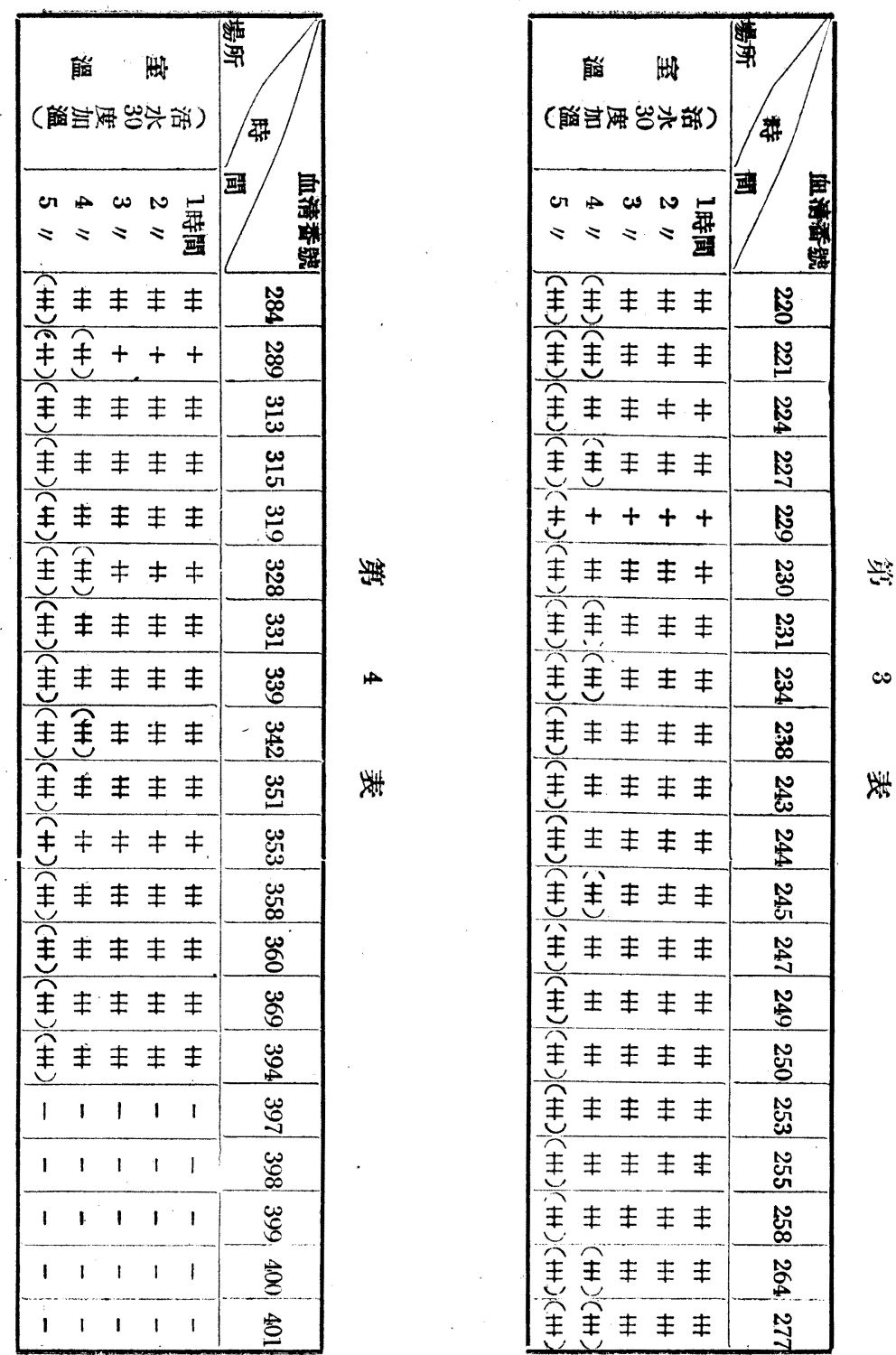

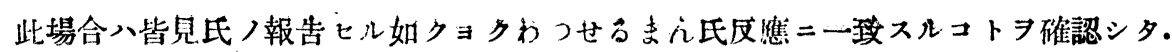

\section{第 3 第 活水 $ヨ$ 零度二椧却シタル場合}

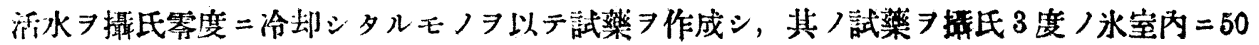


分間靜置シタル後，可檢血清二重疊シテ再ビ其ノ水室內二放置シタル場合ノ成績八第 5 表， 如クデアツタ. 倘此ノ對照トシテ零度ノ活水

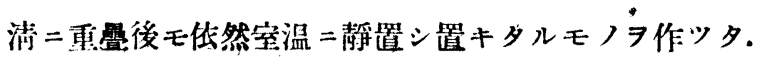

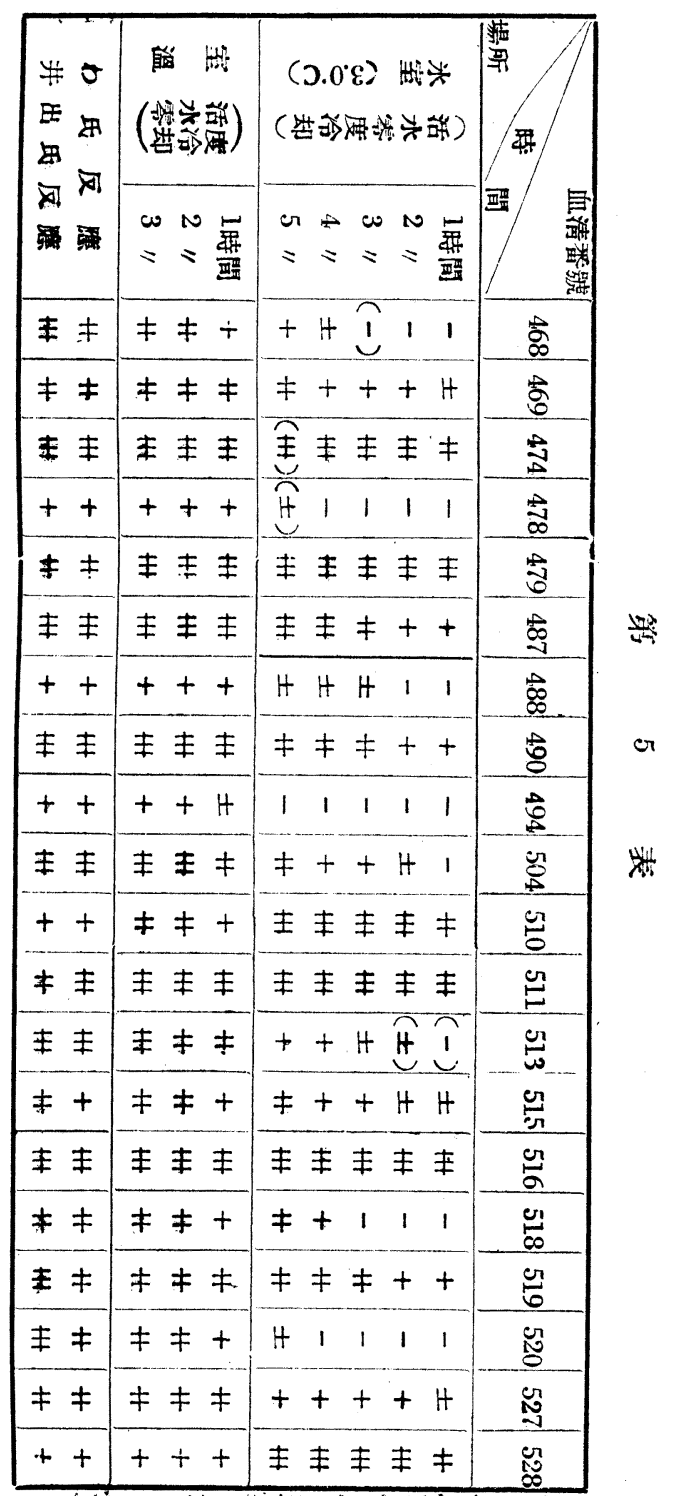

然ルトコ口氷空內二置ケルモノ 八反應速度甚ダ緩慢ニシテ，5 時 間ヨ經過シテモ弱陽性程度ノモノ 八殆ド反應习認識シ得ラレナイガ 龉照群ニアツテハ殆ト原法卜變ル トコロナク反應ガ仙現シ得タノデ アル.

\section{第 4 篇 餒卵器 リ水室二圈換七ル 場合}

第 2 時润目二置キ換ヘタル場合

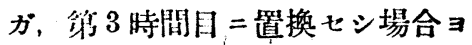
リモ反應柱現時閒八短縮七ラレル。 ソシラ兩者二共通シタル現象トシ テ八反應ガ一時抑制セラレル仳问 ノ存スルコトデアル。佾 3 時間 $=$ テ八弱是性程度以下ノモノ八發現 シナイシ，時トシテ確實二㓌怢ナ リシモノニ於テ矮性反應 $习$ 現入ス コトガアル。

（第6表及第7表寥照） 


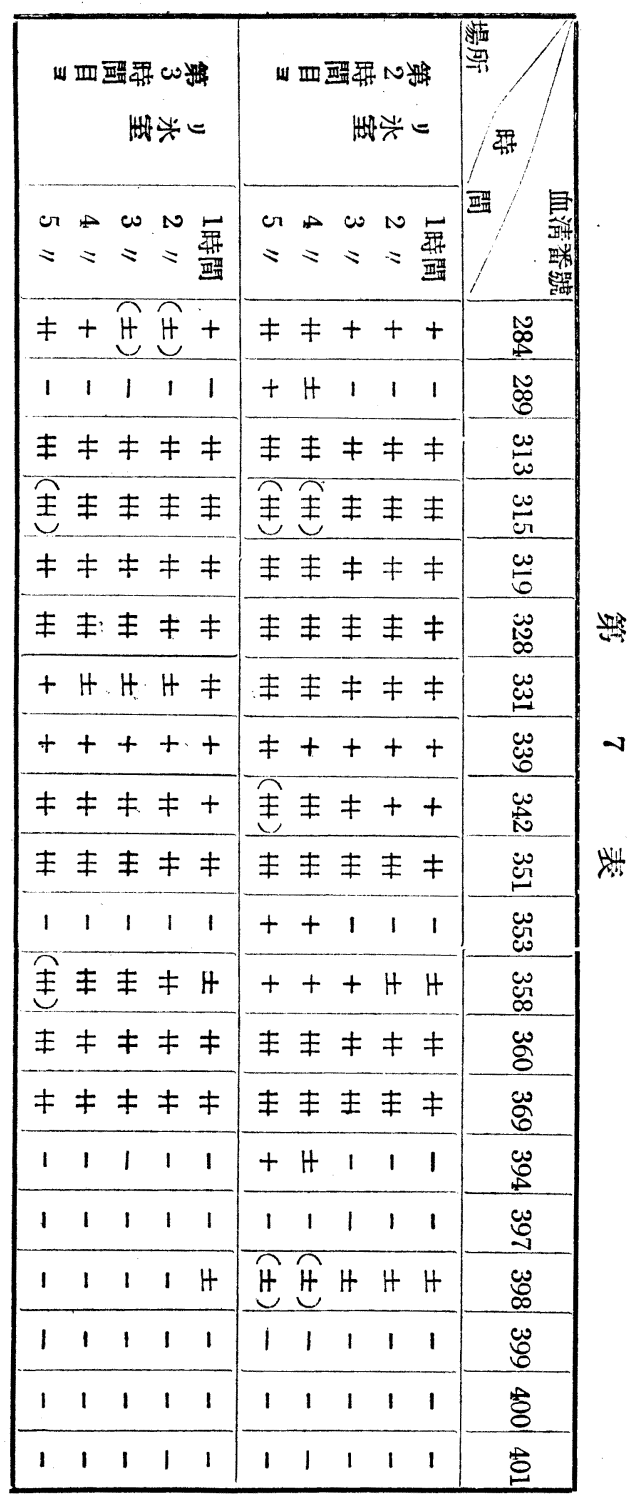

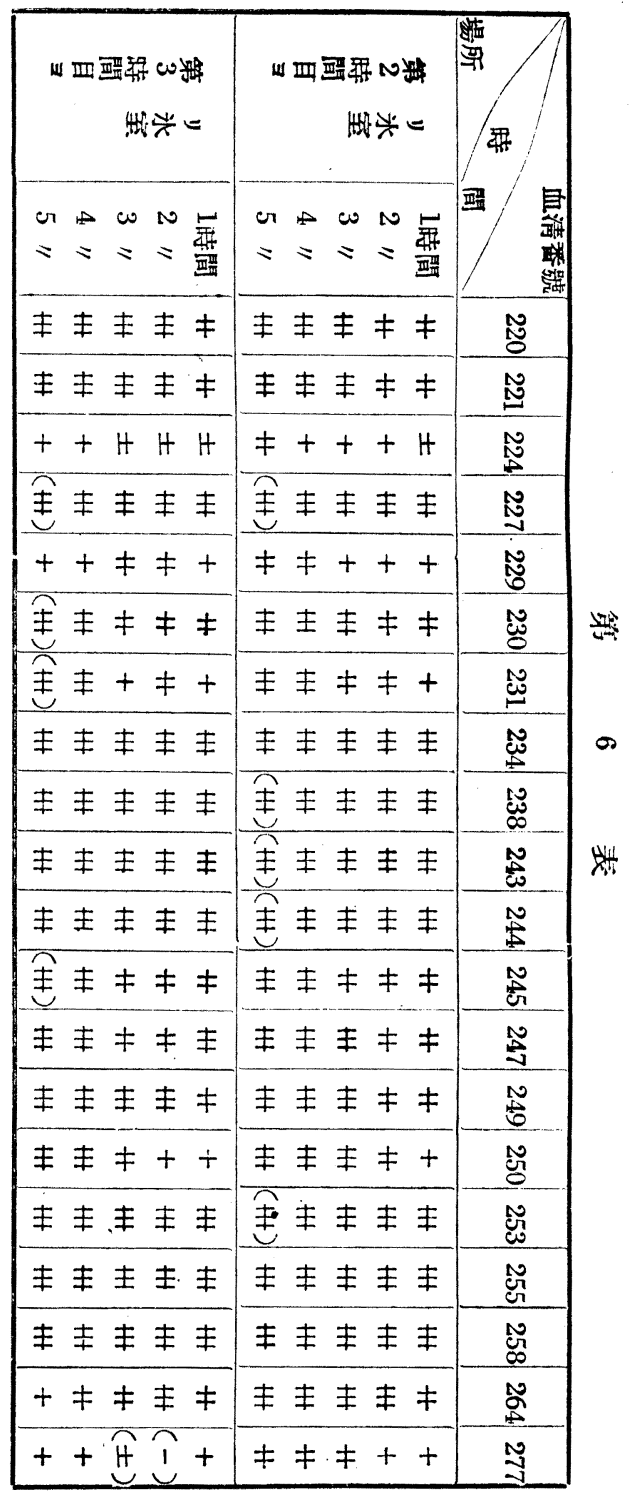

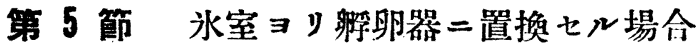

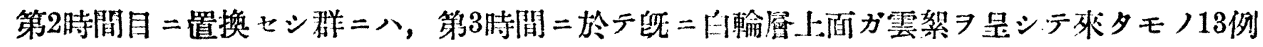
(32.5\%) アツタガ，第3㭙間目=置換七シ群ニハソレガ僅カ=4例 $(10 \%)=$ 過戊ナカツタ. 他方反應ノ促進七ル現象八認メラレナカツタ.（第 8 表及第 9 表參贸） 


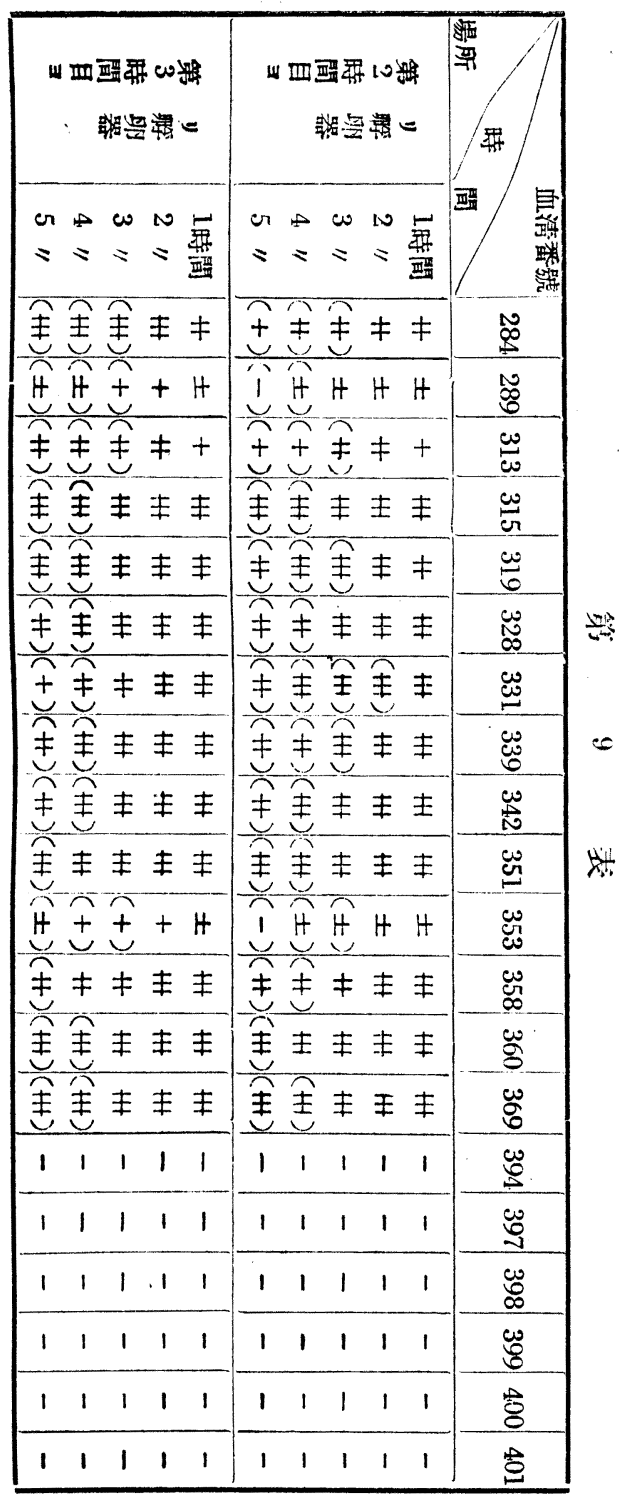

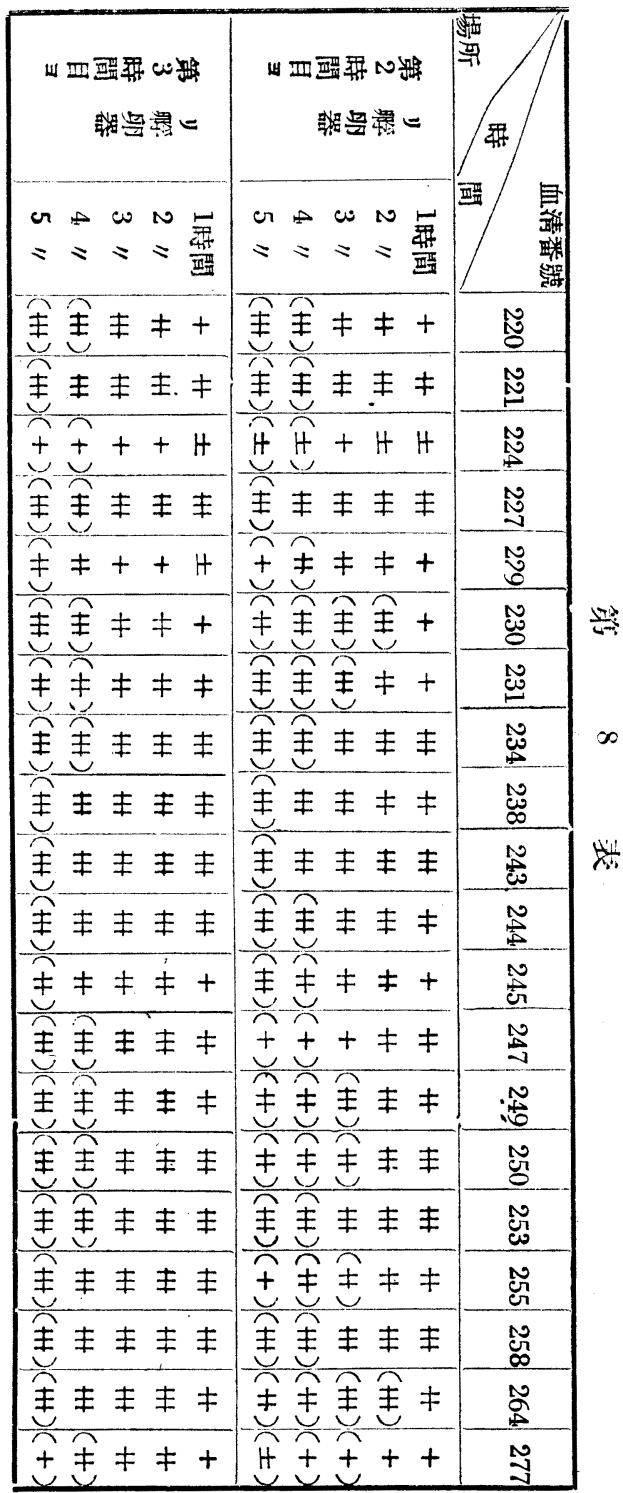

第 4 章 總括並二考察

茲二本實驗 ノ結果 7 總括スル

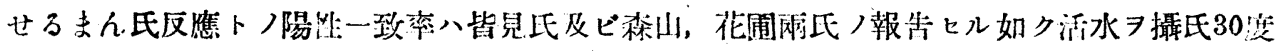

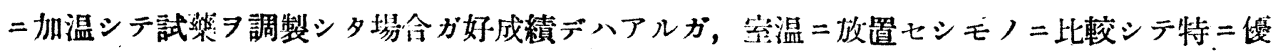


(602)

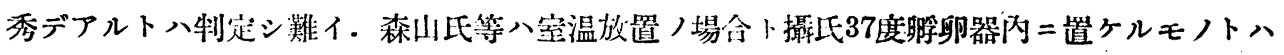
大差习認メズシテ, 水室內放置ノ場合二大差アル由ヨ報ゼルモ, 余ノ實驗ノ結果デ八之ト全

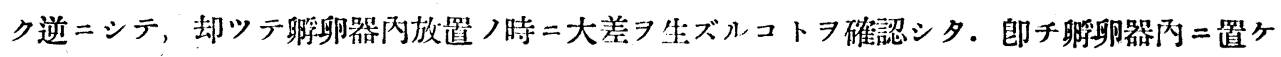

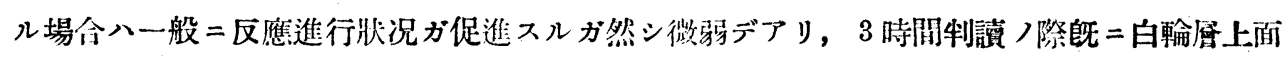

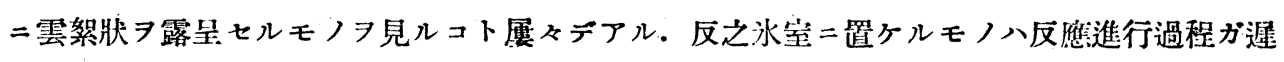
延シテ, 空温ノ場合ニ於ヶル 3 時間制讀つ程度ハ漸ク 5 時間目ノ終り頃ニ發現スル。然シナ ガラ睬卵器內二置ゲ場合ョリモ遙カ二好成績デアル。

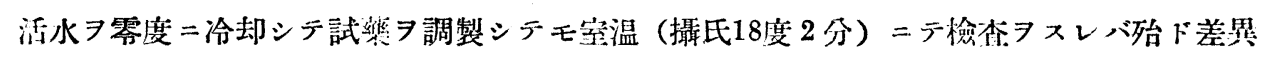

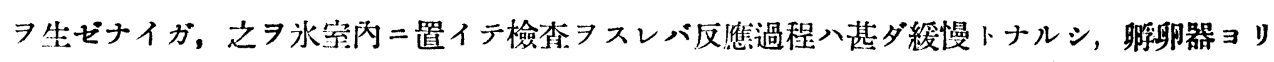
水室二置換七ル場合二八其, 置換時ノ相違ニヨツテ潦異ヨ生ジ，古ク置換七ルモノ程反應山 現狀態がョイ. 又水室ョリ孵卵器內二置換七ル場合、，冚只置換七シ場合程反應不鮮明ナル

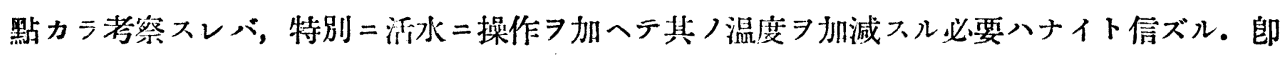

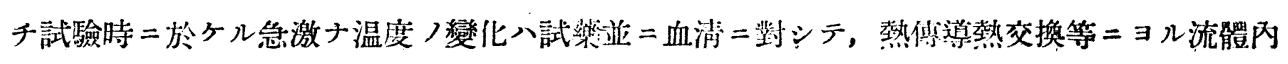

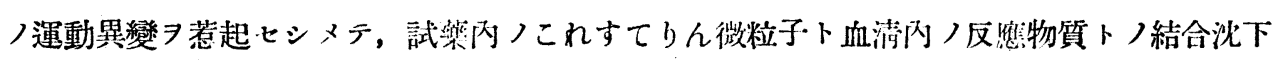
スルコトヨ惑亂スルタメデアラウト考へル。ツマリ試驗時ノ温度高キ際八これすてりん微粒 子ヤわつせるまん氏反應物質/運動が活潑トナリ。溫度低キトキ八此等/運動ガ不活潑トナ ルタメ二前者ノ場合八反應ガ迅速ニナルケレトモ充分ノ絬合が行ハレナイ倠二運動シ, 後者 八場合二八反應八徐々二進行スルヶレトモ其ノ結合八完成セラレテ或ル・定ノ大イサ二達ス ルカラ沈下シテ反應ガ明瞭二現ハレルモノト推斷スル。從ツテ村H低反應モ檢查室內ノ溫度 ヨ或ル一定ノ範園內二調節スルカ. 或ハ小林, 时岡, 西村氏法ノ如ク恒溫裴置內二テ劉施七 バ森山氏等ノ報告セルガ如キ季節的變動卜思惟七ラレル現象八發現シ得ナイト信ズル。本實 驗ヨリスレバ檢查室內ノ溫度八攝氏 37 度以下, 同 4 度以上デナクデハナシナイコトニナル。

\section{第 5 章結瞃}

以上ノ貫驗カラ次ノ如キ知昌 7 得タノデアル。

1. 村明氏反應入氷室內 (攝氏 4 度) 放置ノ場合ニハ反應䌊徐ナレドモ原法二近似ヒル成 績フ示ス. 但シ此ノ場合判讀時間 75 時閂マデ延長スルコトラ要スル。

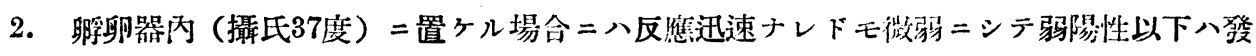
現シナイコトガ多イ.

3. 活水 7 攝氏 30 度二加溫シタルモノヨ以ツテ試染ヨ調製シタル場合ノ反應成績ハ良好テ アル. 


头田 長 次 耶 进

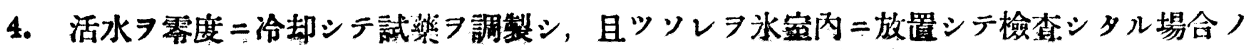
反應成樍ハ不良デアル。

5. 活水 零度 $=$ 冷却シテ試桨 調製シ, 目ツソレタ室溫ニテ檢杳シタル場合ノ反應成績 八原法ト殆ド后翼ハナイ・

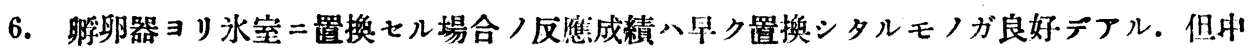
等度陽性以下ノ归現率ハ良クナイ。

7. 水室ヨリ餒卵器內二置換セシ場合ノ反應成績ハ早ク置換シタルモノ程不良デナル。

8. 檢查時ノ溫度ガ攝氏4度ナルトキハ原法卜異ラザル成績ヨ示スモ, 同3度ナルトキハ战 績甚ダ不良デアル。

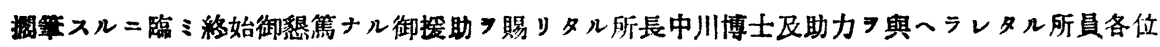

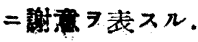

\section{文献}

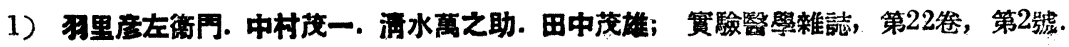

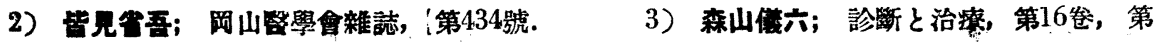

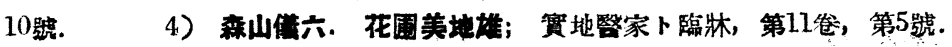

